of protein, and energy-giving foods instead of carbohydrate. Initially such a technique may provide a graphic description for the layman, but in the long run as a result of it people may imagine that high-protein foods do not contain calories, and that without sugar we would lack energy.

(b) A misinterpretation of what has been said or written. One sentence from a balanced statement taken out of context, or a misunderstanding of the overall philosophy behind a research publication, may lead to total misjudgment of the conclusion.

(c) The publication of inadequate research which is accepted for more than its worth.

(d) The time lag between the initial production of research findings and their general publication. For example, it might take io years or more between the unearthing of a new fact and its appearance in a text book.

(e) The role of the judgment factor in nutrition. The subject is in many ways a deductive one, involving the subjective valuation of objective criteria. As such, human fallibility may lead to the wrong conclusion.

(f) The difficulty of defining who is an expert in a field so close to human life, where everybody regards themselves and even calls themselves experts on food.

The solution lies in teaching people how to look for information, and how critically to assess its value rather than in simply giving them facts which is what so often occurs. Perhaps also organizations such as The Nutrition Society need to make authoritative statements to the press and the other media which can stand against, and even positively attack, the well-publicized views of the charlatan.

\title{
Keeping up to date in nutrition: Chairman's summary of the discussion
}

\section{By S. K. KoN, I5I The Warren, Caversham, Reading}

By arranging today's colloquium, The Nutrition Society offered to its members a type of meeting novel for them, though well known and popular in other scientific societies.

Time alone will tell whether such informal exchanges of views on specialized topics of current interest, at which brief papers by invited speakers provide a strutting for general discussion, will find lasting favour with our members. There is no doubt that this particular meeting appealed to many: not only was the attendance so large that the venue had to be moved from the Sir John Atkins Laboratories to the main hall of Queen Elizabeth College, but some thirty people took part during a crowded $9 \circ$ minutes in a lively debate between the paper readers sitting as a panel and members of the audience speaking from the floor.

Though neither panel nor audience was agreed on the imminence and dangers of an information explosion, the view seemed to prevail that what is a swelling torrent of papers in one discipline may only be a sluggish stream in another, and that fashions chop and change. With the science (or art) of nutrition, the rate of publi- 
cation of papers of the more traditional type is certainly very leisurely compared with that about the biochemical or biophysical fundamentals of nutrition.

There was amusing cross talk about the viability of the written scientific word. Some suggested, perhaps puckishly, that anything more than 5 years old does not deserve retrieval. More prudent people, probably correctly, thought it best to assess viability by the topic, with papers on topics of bandwagon nature ageing quickly and dying with the fashion, and others more durable in their value.

The audience was quick to perceive that what it was told about retrieval and conveying of information was tailored for the research worker rather than for the teacher, administrator or popularizer, and the needs of the research worker took the lion's share of the discussion. When it came to what the customer wants there was a large measure of unanimity on the part of the users in still asking for abstracts in preference to title lists, or code words, or similar computer distillates, and in wishing for good coverage. It was, of course, evident and accepted by all that some form of selection of material is not only unavoidable but essential. But the consensus of opinion favoured selectivity by scope, not by subjective assessment of 'merit'. Let, say, I 50 (or 1500 for that matter) scientific journals be chosen from the 30000 or 50000 reputedly published, and let every relevant paper in them be abstracted, the separation of sheep from goats being left to the reader. The prospective customers made it clear that they want to know what the abstracting service covers for them and that they want to decide for themselves whether the papers the abstracts lead to are good, bad or indifferent.

It might have been at first sight surprising that the audience showed little interest in the technicalities of retrieval of information, but then it was perhaps natural that the customer who wants a finished product is not particularly concerned about methods of manufacture. Computers, a necessary part of modern information services, were taken for granted, and there was no evidence of their being held in any awe as sensient machines bristling with mechanical DNA, clever enough to decide what is good for the customer and forceful enough to spoonfeed him with it.

The research worker could thus be reasonably satisfied with his window shopping but, though Mrs. Nilson's cri de coeur evoked much sympathy, no easy solution appeared of the problems of the teacher and popularizer. There was a feeling that some form of enlightened authoritative review stripped of specialized jargon might be helpful, but who would write it, and how, in the face of fierce competition for talent by commercially sponsored reviews, often overlapping and repetitive, mainly intended to lure the research worker, nobody could tell. Perhaps a glimmer of hope came from Dr Blaxter's suggestion of selective dissemination of information. A selection would still be indigestible to the harrassed teacher thirsting for suitable information to pass on, but perhaps sufficiently boiled down in size to allow selfless and competent popularizers to convert it into good nourishing leaven.

Dr Mellanby's plea that people be allowed to write and publish whatever the consequences wound up the colloquium, and audience and panel alike went to enjoy their wine and cheese party with a hopeful note of being able to keep up to date in nutrition lingering in the air. 